University of St. Thomas, Minnesota

UST Research Online

\title{
The Antecedents and Impact of Industry Consultants on the Future Performance of New Banks
}

\author{
Michael L. DeVaughn \\ University of St. Thomas, Minnesota, Deva2917@stthomas.edu \\ Myleen Leary \\ Montana State University, myleen.leary@montana.edu
}

Follow this and additional works at: https://ir.stthomas.edu/ocbmgmtpub

Part of the Business Administration, Management, and Operations Commons

This Paper is brought to you for free and open access by the Management at UST Research Online. It has been accepted for inclusion in Management Faculty Publications by an authorized administrator of UST Research Online. For more information, please contact asle4660@stthomas.edu. 
MRR

40,11

\title{
The antecedents and impact of industry consultants on the future performance of new banks
}

1142

Received 26 July 2016 Revised 20 March 2017 29 April 2017 Accepted 15 May 2017

\author{
Michael L. DeVaughn \\ University of St. Thomas, Minneapolis, Minnesota, USA, and \\ Myleen Leary \\ Montana State University, Bozeman, Montana, USA
}

\begin{abstract}
Purpose - The purpose of this paper is to examine the antecedents and performance outcomes when startup firms in the US banking industry hire industry consultants.

Design/methodology/approach - This study uses a sample of prospective startup banks that applied for a new bank charter application in Florida between 1996 and 2005. Logistic regression, ordinary least squares or ordered logistic regression models were used to test hypotheses.

Findings - Analysis suggests complexity and regulatory change are factors in a founder's decision to hire a consultant. Consultants have a positive impact on firm financial performance but not on a composite multifactor measure of performance. Additional analyses suggest the effectiveness of consulting assistance hinges on specific attributes of the consulting firm, but cumulative consulting experience is not one of these attributes.

Research limitations/implications - This study focuses on the impact of consultants on new venture performance in a single industry using archival data. Additional research is likely needed to test the generalizability of the findings in other research contexts and examine motives beyond the financial ones investigated in this study.

Practical implications - Results suggest that hiring a consultant at startup can satisfy financial stakeholders, but, in a regulated industry, hiring a consultant at startup does not improve a composite, multifactor measure of performance that is important to industry regulators. When deciding whether to commit scarce resources to hiring consultants, founding teams should be clear which external stakeholder and which measure of performance they are seeking to improve.

Originality/value - While the business advisory role of informal players such as family and friends and more formal players such as board members and federal, state or local governments have been well documented, little attention has been paid to the contributions of industry consultants in startup firms. These overlooked intermediaries play an important role in the successful launch of a new firm. This study examines when and why such advisors might create value for new firms.
\end{abstract}

Keywords Performance, Legitimacy, Complexity, Consultants, New banks, Regulatory change

Paper type Research paper

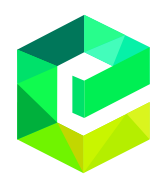

\section{Introduction}

The market for management consultants is a growing one. In 2016, the number of worldwide enterprises providing such assistance was approximately 715,000, up nearly 30 per cent from a decade earlier. With an expected increase of 164,000 additional firms in the next five years, the industry will generate more than US\$258bn in revenues by 2021 (Palmer, 2016).

Despite its size, the management consulting industry is highly fragmented. The industry Vol. 40 No. 11,2017 (c) Emerald Publishing Limited 2040-8269 
predominantly local and niche markets. Consultants, or "knowledge entrepreneurs" (Schaffer and Thompson, 1992), represent a valuable managerial resource for organizations, as they offer knowledge and skills that help managers cope with the challenges of environmental and organizational change. While demand for consulting services has emanated from several different sectors, demand has been strongest in the areas of healthcare and financial services, two industries undergoing significant change (Palmer, 2016).

The growing prominence of consulting has also led to increased academic interest in the field, particularly in consulting activities around small and new firms (Stevenson and Sahlman, 1988; Soriano, 2003; Dyer and Ross, 2008; Chrisman et al., 2012). Chrisman et al. (2012), for example, focus on new firms that receive consulting advice from US small business development centers. While Stevenson and Sahlman's (1988) emphasis is also on new firms, they go further and advocate for the use of consulting "specialists" (rather than general business consultants) who bring contacts and intimate knowledge of problems facing new businesses in a specific industry.

Following Stevenson and Sahlman (1988), the focus of this study is on the antecedents and impact of industry-specific consultants in startup firms in the US banking industry, an industry where consultants routinely assist new firms with startup activities due to regulatory requirements. Specifically, this study investigates two questions:

$R Q 1$. What factors inform a founder's decision to seek assistance from industry consultants?

RQ2. Does such assistance impact firm performance?

The results indicate that complexity and regulatory change are influential factors in a founder's decision to engage a consultant. The results also suggest that consultants, in general, have only a modest positive impact on firm financial performance and no impact on performance using a broader, regulatory measure. This work contributes to the literature on outside assistance in new firms by identifying a set of antecedent conditions under which true startup firms might use outside consultants and linking this use to different measures of performance to consider its impact.

\section{Theory development and hypotheses}

Definition of industry-specific consulting firms

The term "consulting" can encompass a wide range of both actors and activities and has been broadly defined and applied in the existing management literature (Semadeni, 2006; Anand et al., 2007, Fincham et al., 2008). Before proceeding with theory and hypothesis development, it is important to provide a context for the consultants that are the focus of this study and explain how they are similar to, or different from, consultants that have been studied in the management literature.

The industry-specific consultants in this study typically maintain a single industry practice, are generally small organizations with just a few consultants and have a more narrow state or region-wide geographic focus. These consultants are more likely to be hired for short-term, discrete projects, especially under conditions of high environmental change. For example, Smith (2013) notes that because of the passage of the Affordable Care Act in 2010, many specialist health-care consulting firms emerged to help healthcare organizations navigate industry change and "steer clients through an increasingly crowded regulatory minefield” (Smith, 2013, p. B1). These industry-specific consultants are representative of the types of consultants that are investigated in this study. 
MRR

40,11

1144
Antecedents of consultant use

Uncertainty is an important undercurrent in a founder's decision to seek external advice. Milliken (1987) argues that individuals experience uncertainty because they perceive that they lack the appropriate information to accurately predict an outcome. Similarly, March and Olsen (1976) maintain that organizations routinely experience uncertainty about the policies and practices of their firms. A founder operating a fledgling new firm is likely to experience such uncertainty and may be inclined to adopt specific strategies and practices to manage this uncertainty. These strategies or practices could include the use of consultants to establish legitimacy, reduce information processing demands activated by complexity and decipher the implications of regulatory change. Each is explored in more detail below.

Legitimacy. Successfully launching a new enterprise is inherently uncertain. This is especially true in the US banking industry where close observers estimate that almost half of prospective new bank founders who explore starting a new bank, ultimately elect not to do so (Austin et al., 1999). Institutional theorists (DiMaggio and Powell, 1983) maintain that organizations attempt to manage uncertainty in their environment by seeking legitimacy. Legitimacy can be considered a status conferred by important social actors in an organization's environment that suggests both desirability and normativity (Pfeffer and Salancik, 1978). Mimetic isomorphism, the tendency to imitate others, is a primary mechanism by which organizations seek to establish legitimacy (Meyer and Rowan, 1977; DiMaggio and Powell, 1983). Faced with environmental uncertainty, organizations will tend to imitate the structures, strategies or practices of other similarly situated organizations, especially if these referent organizations appear to be successful. Conforming to norms of expected behavior signals that an organization is acting in an acceptable manner and social actors should evaluate it as legitimate (Deephouse, 1996). Conversely, a behavior that deviates from the norm is likely to lead to negative evaluations by these same social actors.

Prior research has largely confirmed the occurrence of such legitimacy enhancing imitation. In a study of how organizations choose professional service firms, Haunschild and Miner (1997) found that such imitation could be based on frequency (i.e. copying common industry-wide practices), traits (i.e. copying the practices of organizations with certain relevant features) or outcomes (i.e. copying practices based on their apparent impact in the market). Knoke (1982) found that the adoption of reforms by government municipalities was influenced by the proportion of prior municipalities also embracing such reforms. Likewise, Burns and Wholey (1993) found that the adoption of matrix management structures by prestigious hospitals in a region subsequently affected the adoption of those same management structures by other hospitals in the region. Davis (1991), however, found that the spread of the poison pill - a takeover defense strategy executed by boards of directors in an industry was unrelated to the proportion of prior adopters in the industry. Davis' (1991) study notwithstanding, most research has generally supported the notion that organizations tend to imitate one another in an effort to increase their legitimacy.

In the financial services industry, government regulators have been identified as an important social actor for banks (Deephouse, 1996), as founders must secure the endorsement and approval of government banking regulators to establish a new bank. As such, prospective bank founders may be motivated to engage in actions that increase its legitimacy with this important audience. For example, a Florida business trade publication (South Florida Business Journal, 2006) noted that a prospective bank founder in the Miami area had been unsuccessful in launching a new bank because he had followed the "rare strategy" of not using a consultant during the bank's startup process. By hiring a consultant and adopting a strategy that is consistent with normative industry behaviors, a new bank can signal its legitimacy to banking regulators. 
Thus, if prospective bank founders are motivated to engage in legitimacy enhancing behavior, such as using a consultant to assist in the startup process as a means of managing the uncertainty associated with regulatory approval of a new bank, one manifestation of such behavior would be an observed positive relationship between the proportion of prior new banks that used a consultant at startup and the use of a consultant at startup by the focal bank.

H1. There is a positive relationship between consultant use at startup by the focal bank and the proportion of banks (in the state) that engaged a consultant at startup.
Future

performance of new banks

Complexity

One popular view of the complexity of an organization's task environment portrays complexity in terms of the heterogeneity and range of an organization's activities (Thompson, 1967; Duncan, 1972). Researchers who adopt this view suggest that managers who operate in such complex environments perceive greater uncertainty and have far more information processing requirements than managers facing more simplistic environments (Tung, 1979).

Another view (Evan, 1966) contends that the complexity of an organization's environment can be characterized by both the number and variety of other organizations in the focal organization's "organizational set" with which it must interact to resolve critical contingencies. These views converge around the fact that the complexity of an organization's environment is contingent on either the variety or number of activities it involves itself in or the variety or number of players that constitute its organizational set.

Complex and turbulent environments have been shown to increase information processing demands on managers (Dess and Beard, 1984; Haleblian and Finkelstein, 1993), while simple, less intense environments have been shown to require less information processing (Kotter, 1982; Ancona, 1990). It has been argued that one of the ways that managers can cope with increased information processing demands is by expanding its top management team, as larger teams bring enhanced capabilities and more perspectives to bear on a problem (Finkelstein and Hambrick, 1996). Hiring additional managers reduces the information processing burden for the organization's CEO (Miller, 1992). Another way in which founders can adapt to the increased information processing demands of a complex task environment is by engaging outside experts, such as consultants, for specific tasks. Conceptually, this has an impact similar to expanding a top management team, as the new firm now has access to additional knowledge and resources. However, the approach of hiring an outside consultant differs from expanding a top management team in that it does not require a long-term employment commitment and an outside expert can be hired for their specific knowledge related to a component of a new bank's startup process.

Launching a new enterprise is a complicated task with many requirements and in the banking industry this task is further complicated by the need to seek approvals from different regulatory entities. A new bank's choice of strategy and organizational form has the potential to complicate the bank's approval path. For example, the decision to adopt a bank holding company structure at startup means that a prospective founder must file a separate bank charter application with a federal regulatory agency, recruit additional board members to serve on a second board of directors to oversee the bank holding company and prepare a second set of financial projections and statements to account for the bank holding company's activities. These tasks would not be required of a prospective founder who chooses to launch a new bank using a simpler organizational structure (Austin et al., 1999). Thus, founders who elect to pursue strategies that call for complex organizational structures 
MRR 40,11

1146 will face a much more complex task environment at startup because of an increase in the number and variety of regulatory requirements. To manage the increased information processing demands imposed by the more complex task environment at startup, founders may seek consulting help.

H2. There is a positive relationship between the use of a consultant at startup by the focal bank and the complexity of the proposed organizational form of the new bank.

Regulatory change. In a study of California hospitals and savings and loan associations, Haveman, et al. (2001) classify regulatory changes that are likely to drive organizations to alter their strategies, structures and activities as "regulatory punctuations". Such changes are characterized by extensive shifts in constraints on business operations that can trigger pressures to modify the rewards and penalties for organizational actions and create uncertainty regarding optimal strategies for organizational action (Haveman et al., 2001). Similarly, Milliken $(1987,1990)$ adds that such changes create "response" uncertainty where organizational decision makers are uncertain about the range of response options as well as their comparative value and utility relative to the organization's goal. Discontinuous changes resulting from regulatory modifications can be difficult to cope with and the net effect is to raise the level of uncertainty for key players in the organization.

Major banking regulatory changes can greatly expand the strategic and structural alternatives available to prospective bank founders at startup. The availability of new choices can generate response uncertainty among prospective bank founders, and these changes can disproportionately impact new entrants. Founders may seek advice to help them assess the utility of an extended set of unfamiliar alternatives. Moreover, multiple regulatory changes can produce a "cascading" effect whereby the current period is more complicated and uncertain than the period that preceded it, making more likely that a prospective bank founder will use a consultant in the current period than in a prior period. Therefore:

$H 3 a$. In the period following a major regulatory change, consultant use at startup by new banks will increase.

$H 3 b$. Following an additional major regulatory change, consultant use at startup by new banks will increase relative to the preceding periods.

\section{Performance implications}

Consultants have emerged as an important resource to help new firms navigate the nonroutine, complex and uncertain conditions that characterize the startup environment. Founders, especially those without previous entrepreneurial experience, often come to realize that they lack critical knowledge in this domain and that specialized industry consultants possess valuable expert knowledge that can help them bridge this gap. Fincham et al. (2008) point out that due to repeated assignments with similar clients in the same industrial sector, specialized industry consultants accumulate specific, detailed knowledge that is relevant to the new venture in that sector. Such knowledge can range from general "know-how" to specialized "privileged" knowledge that leverages technologies and relationships built by the consultant. Access to this knowledge represents one of the new firm's most important potential advantages (Chrisman et al., 2005).

As outlined above, founders are hypothesized to use consultants to increase legitimacy, deal with complexity and manage change with respect to their new firm. However, there is an implicit assumption that the decision to use a consultant is considered without regard to 
the potential effect on firm performance. While consultants engaged in short-term relationships with firms may be focused on the specific task at hand and not the firm's bottom-line, the goal of nearly all consultants is to improve firm performance (Dyer and Ross, 2008).

When consultants are able to transform their accumulated knowledge into distinctive and meaningful strategies for their clients, they help launch a positive performance trajectory for the new firm, setting it apart from others that do not have access to this critical knowledge (Werr and Pemer, 2005). Expert knowledge offered by consultants can provide new banks with an advantage, helping them to move effectively and efficiently through the startup process. The sooner the new bank receives its necessary approvals, the sooner it can open for business and begin earning a return for early stage investors. Additional costs associated with hiring a consultant are likely to be offset by greater efficiency and increased speed to market, improving the overall financial performance of a new bank.

As entrants in a regulated industry, new banks must concern themselves with how their performance will be measured by regulators, as well as financial stakeholders who are focused of traditional measures of financial performance. Regulators evaluate banks on a broad composite measure of performance that considers the "safety and soundness" standards that they are directed to uphold. This measure consists of six factors, including bank profitability a customary measure of bank financial performance. Given that prior research has found a positive relationship between firm performance and consultant use (e.g. Larsson et al., 2003; Chrisman et al., 2005), a positive relationship between a new bank's consultant use and its financial performance as well as the broader, multifactor composite measure of performance used by regulators is expected. Therefore, it is hypothesized:

$H 4 a$. New banks that use a consultant at startup will see a greater impact on financial performance than those new banks that do not use a consultant.

$H 4 b$. New banks that use a consultant at startup will see a greater impact on a multifactor composite measure of performance as measured by bank regulators than those new banks that do not use a consultant.

\section{Research method \\ Sample}

The data set for this study includes the population of new bank charter applications submitted to the Florida Office of Financial Regulation (FLOFR) between 1993 and 2005. This timeframe and state was selected because it was a particularly robust period of new bank chartering in the USA where nearly 2,000 new banks were formed and Florida led all states with 161 new banks (FDIC Institution Database www.fdic.gov). Given this study's focus on new bank launches and their performance in the subsequent three calendar years, it is important to capture a time period of munificent bank startup activity. While the launch data for new banks in the study ends in 2005, the performance data for these banks extends to 2008 (three calendar years after the last launch date), ending just before the onset of the global financial crisis. It is also important to note that the global financial crisis ushered in a period of heightened regulatory scrutiny for financial institutions which effectively, suppressed new bank startup activity in the USA[1] during and after the crisis.

During the period of the study, FLOFR received a total of 149 applications for new state bank charters, of which 127 were ultimately approved. After dropping observations because of missing data on one or more variables, the sample consisted of 123 useable observations. This sample was used to test the hypotheses predicting consultant use. 
MRR 40,11

1148
A subset of the sample above was used to test the hypotheses regarding the performance impact of consultants. The sample includes banks that commenced operations prior to the end 2005, to allow for each bank to accumulate three full calendar years of performance. This three-year window is consistent with the period when regulators intensely scrutinize new bank performance. After accounting for banks that were acquired prior to the end of the three-year screening criteria or were missing data on one or more variables, a sample of 68 observations remained for testing the performance hypotheses.

Data

Information on the use of bank consultants was collected from FLOFR, a state-level bank regulatory agency responsible for chartering new banks in Florida. Demographic and structural information on the banks in the study was collected from the FDIC's Institution Database, a repository that lists all active and inactive banks that maintain federal deposit insurance.

Information on the backgrounds and characteristics of startup bank founders was compiled using local, regional and national bank trade publications as well as local business publications from a variety of geographic locations in Florida. Information was also taken from biographical entries on new bank charter applications submitted to FLOFR.

Performance data were compiled using information from the FDIC's Reports of Condition and Income ("Call Reports") and from Weiss Ratings Inc., an independent bank rating agency that measures the performance of banks on a variety of dimensions. Finally, Thomson's North American Financial Institutions Directory was also used to identify bank founders and to cross-validate other demographic entries taken from the previously mentioned sources.

Measures: antecedents of consultant use model (H1-H3b)

Dependent variable. The dependent variable is an indicator variable that represents whether a bank's founder used an industry consultant during the startup phase of the bank (consultant). This information is taken directly from the bank's initial charter application that was filed with FLOFR.

Independent variables. A proxy for the relative popularity and imitability of the practice of using consultants during startup was calculated using the proportion of all startup bank applications that were filed in the state with the help of consultants in the three years prior to the focal startup bank's application (per cent prior banks with consultants). The three-year window of this measure is consistent with the "peer group" categorization that bank regulators use when evaluating the performance of startup banks and follows Haunschild and Miner's (1997) assertion that any indicator of other firms' experience that is longer than three years is likely too old to influence the focal firm.

The presence or absence of a single bank holding company at startup, $(\mathrm{SBHC})$, is used as a proxy for the complexity faced by bank founders at startup. An SBHC, an affiliated "shell" parent corporation, is advantageous in that it can expand the strategic opportunities for a startup bank, but also disadvantageous as it increases the regulatory burden of the bank. In addition to following the rules of its state and federal bank regulators, a new bank with an SBHC must also apply to and abide by the rules of the Federal Reserve Bank. Close observers of the banking industry maintain that adding an SBHC during startup materially complicates the startup process and is generally a less efficient approach to opening a new bank (Austin et al., 1999).

Regulatory changes were measured using a period-effect orientation (Haveman et al., 2001). In this approach, discrete periods were identified when regulatory changes were likely 
to affect the practices and behaviors of organizations. During the period of the study, there were two important regulatory changes that significantly broadened the number and variety of strategic options that were available to startup banks[2]. The first was the passage of the Small Business Job Protection Act of 1996. The second was the GrammLeach-Bliley (Financial Services Modernization) Act of 1999.

The impact of these regulatory changes was accounted for by creating indicator variables representing the three periods affected by the regulations. Three distinct periods for startup banks were identified: those banks filing bank charter applications prior to 1997, predating the implementation of the Small Business Job Protection Act of 1996 (bank applications before 1997), those filing between 1997 and 1999 and primarily affected by the implementation of the Small Business Job Protection Act of 1996 (bank applications 1997-1999) and those filing after 1999 and affected not only by the Small Business Job Protection Act but also by the implementation of the Gramm-Leach-Bliley Act of 1999 (bank applications after 1999).

Control variables [3]. Control variables were included to account for other forces that may affect whether a bank founder seeks consultant help at startup. First, variables to control for the relative munificence of the startup environment for new banks were included. As the sample is drawn from a single state, environmental control variables at the county level were measured to account for differences in the local environment for each new bank. These include changes in the population (population), employment (employment) and personal income (income) statistics in the county of the proposed startup bank. In addition, the number of startup bank applications filed during the three-year window prior to the filing by the focal bank (previous de novo banks) were controlled for. This serves as a proxy for the potential level of competition to engage a consultant, a factor that prior research has shown to be important in determining the likelihood of using professional service firms (i.e. Haunschild and Miner, 1997). Collectively, these four variables can account for favorable environmental conditions that may induce bank founders to forgo seeking outside consulting help.

The experience of the lead founder of the bank was also controlled for with an indicator variable, repeat bank founder. This accounts for whether or not a lead founder, as identified in either the bank's charter application or press accounts, has previous bank startup experience. Self-efficacy research (Bandura, 1977; 1984) has suggested that when one has previous experience in executing a task, one's belief in his or her ability to successfully complete that task again increases. Thus, founders with prior bank startup experience may see no need to seek consulting help.

Other resources that may be available to assist bank founders during startup were also included as control variables. The size of the initial board of directors of a new bank at startup (founding board size) was calculated and used as a proxy for the resources available to bank founders. Consistent with a resource dependence view of the board of directors (Pfeffer and Salancik, 1978), bank founders with larger boards may have more resources (financial, human, social, etc.) at their disposal and as a result, may be less likely to rely on consultants.

Measures: performance implications of consultant use (H4a-H4b)

In the performance implications of consultant use model, a smaller sub-sample of the original data was used, as well as an expanded set of independent and control variables to measure the impact of consultant use at startup on new bank performance.

Dependent variables. Two measures of performance were included in the analysis to account for the interests of the two most relevant stakeholders in this research 
MRR 40,11

1150 context-shareholders and government regulators. The first measure is return on equity (ROE), a standard measure of general firm performance and profitability in the banking industry. A bank's ROE is computed by dividing its net income by its average equity capital. It is worth noting that whether ROE is a positive or negative value depends fully on the value of the numerator (net income). This is because government regulations require banks to maintain a minimum level of capital to operate, meaning that the denominator of ROE (equity capital) will always be a positive value. Our ROE measure captures the average ROE for a new bank over its first three full calendar years, a time of intense scrutiny by bank regulatory agencies.

The second measure of performance is based on a bank's Weiss rating (Weiss) - a score compiled by Weiss Ratings, Inc., a private bank rating service that measures the relative safety and soundness of all US banks. The Weiss rating is a multifactor composite score based on several components of a bank's performance, including its capital adequacy, asset quality, management capability, earnings capacity, liquidity and interest rate sensitivity. Weiss ratings closely track the CAMELS score system that federal bank regulators use to gauge the overall health and performance of US banks. For the purpose of this study, the Weiss ratings' alphabetical scale was transformed into a numeric scale where $\mathrm{A}+=1$, $\mathrm{A}=2, \mathrm{~A}-=3 \ldots \mathrm{E}+=13, \mathrm{E}=14, \mathrm{E}-=15$. A low score is associated with high performance while a high score is associated with low performance. The Weiss score that corresponds with a bank's rating at the end of its first three full calendar years was used in the analysis.

Independent variable. The independent variable of interest is consulting help. An indicator variable, consultant, was used to denote if the founder of each bank engaged a bank consultant to assist in the startup process.

Control variables. Several of the control variables that were used in the previous consultant use model above were retained to predict the new bank performance with a use of a consultant at startup. These variables include population change, employment change and personal income change. These variables control for economic influences that may impact firm performance.

In this model, other variables that might impact performance were also controlled for. Bank density accounts for the number of existing banks already present in the startup bank's proposed (county) location. Initial equity, a measure of startup capital secured by a new bank, was used to control for the financial resources available to the new bank. Organizational size (asset size) was controlled for by taking the yearly average assets for a new bank over the bank's first three full calendar years. As performance was measured using the first three full calendar years, an age variable (age) was included. This variable represents the number of days between a bank's charter (opening) date and the beginning of its first full calendar year to account for the variation in the number of operating days among new banks, as better performance might be linked to length of operating experience.

To account for differences in management ability, a control variable (net interest margin management) was included. Managing a bank's net interest margin, the difference in interest that a bank takes in on loans and returns on deposits, can be considered a proxy for the operational expertise or capability of bank management. To control for the relative risk and quality of the assets in a bank's portfolio, the control variable problem assets [4], was also included. This variable accounts for the possibility that banks might make high risk and low-quality loans that lead to improvement in performance in the short run, but deterioration in performance in the long run. In addition, two variables to control for characteristics of the bank founder's prior experience were included. Founders that come from outside of the banking industry were controlled for with the variable outsider, as it is 
reasonable to assume that banks headed by founders who have prior industry experience might perform better. The second variable accounts for whether the founder has previously started a bank, repeat bank founder. This variable controls for whether the lead founder has specific bank startup experience, as this might influence the early success of the firm.

Finally, the inverse mills ratio (Mills Ratio) was included in this model to account for potential selection bias. This is necessary to guard against the possibility that there could be unobserved factors (captured by the model's error term) that are associated with the decision to use a consultant that are also correlated with the performance of the consultant. The inverse mills ratio, the ratio of the probability density function to the cumulative probability density function of a distribution, is derived from the first stage of Heckman's (1979) twostage estimation procedure for correcting sample selection bias. In the first stage, a probit model is estimated to determine a key binary choice dependent variable (consultant use). From this model, an inverse mills ratio is determined (using the probability and cumulative distribution functions) and used as an independent variable in the second stage outcome (consultant use) model.

\section{Analyses}

Two sets of analyses were performed. In the first analysis, logistic regression techniques were used to test the claims concerning the factors that are expected to influence a founder's decision to engage a consultant (H1-H3b). In the second analysis, both an ordinary least squares and an ordered logistic regression model specification were used to test the hypotheses regarding the performance implications of consultants $(H 4 a-H 4 b)$. An ordinary least squares specification is used when the performance outcome measure is ROE ( $H 4 a)$. An ordered logistic regression specification is used when the performance outcome measure is a bank's Weiss rating $(H 4 b)$. This specification is appropriate because the dependent variable is a score between 1 and 15 (where 1 represents the best performance and 15 represents the worst) and lower or higher levels of performance are associated with each move up or down the rating scale.

\section{Results}

Predicting consultant use model (H1-H3b)

Descriptive statistics and correlations are presented in Table I. Significant correlations are observed between consultant use and several of the independent variables. Table II shows the results from the model predicting the use of consultants. This model begins with a baseline model of only control variables and expands to include all of the research variables of interest in order to test $H 1-H 3 b$. Based on the results of this model, $H 1$ is not supported; no relationship is observed between consultant use by all prior startup banks and use by subsequent startup banks. Thus, it appears that establishing legitimacy via imitation is not a strong factor in deciding whether to engage a consultant at startup.

On the other hand, the model in Table II shows support for $H 2, H 3 a$ and $H 3 b$. Bank founders seek consulting help in response to complex task environments (H2) and environments characterized by regulatory change ( $H 3 a$ and $H 3 b)$. With respect to regulatory change, the results suggest that founders who filed their bank charter applications after 1999, the third regulatory period, were more likely to use consultants than founders who filed during either the first or second regulatory period. Moreover, in Model 5 in Table II, where the omitted category is changed from bank applications after 1999 to bank applications 1997-1999, there is support for the cascading effect of consultant use as predicted in $H 3 b$. That is, founders who filed their bank charter applications between 1997 


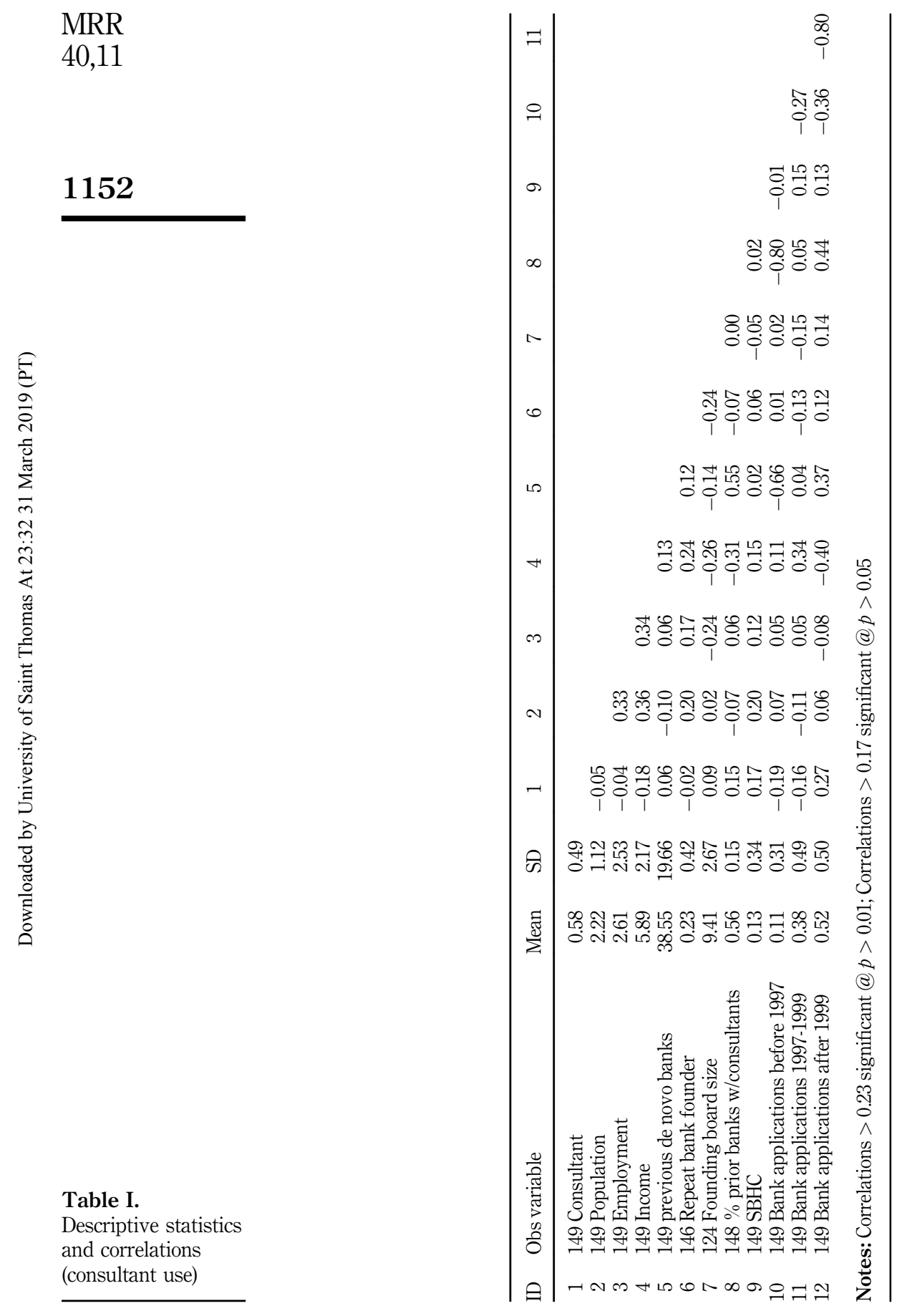




\begin{tabular}{|c|c|c|c|c|c|c|}
\hline Variable & Model 1 & Model 2 & Model 3 & Model 4 & Model 5 & \multirow{3}{*}{$\begin{array}{r}\text { Future } \\
\text { performance of } \\
\text { new banks }\end{array}$} \\
\hline Population & $-0.03(0.19)$ & $-0.11(0.20)$ & $-0.17(0.20)$ & $-0.42^{* * *}(0.23)$ & $-0.42^{* * * *}(0.23)$ & \\
\hline Employment & $-0.02(0.08)$ & $-0.04(0.08)$ & $-0.05(0.08)$ & $0.01(0.09)$ & $0.01(0.09)$ & \\
\hline Income & $-0.14(0.10)$ & $-0.07(0.12)$ & $-0.09(0.12)$ & $0.10(0.15)$ & $0.10(0.15)$ & \multirow{5}{*}{1153} \\
\hline Previous de novo banks & $0.00(0.01)$ & $-0.01(0.02)$ & $-0.01(0.02)$ & $-0.05 *(0.02)$ & $-0.05 *(0.02)$ & \\
\hline Repeat bank founder & $0.34(0.48)$ & $0.52(0.51)$ & $0.47(0.52)$ & $0.16(0.57)$ & $0.16(0.57)$ & \\
\hline Founding board size & $0.05(0.08)$ & $0.06(0.08)$ & $0.06(0.08)$ & $0.04(0.08)$ & $0.04(0.08)$ & \\
\hline$\%$ prior banks w/consultants & & $2.61(2.03)$ & $2.26(2.05)$ & $-2.37(3.02)$ & $-2.37(3.02)$ & \\
\hline SBHC & & & $1.30 *(0.63)$ & $1.66 * *(0.67)$ & $1.66^{* *}(0.67)$ & \multirow{7}{*}{$\begin{array}{l}\text { Table II. } \\
\text { Logit regression of } \\
\text { consultant use }\end{array}$} \\
\hline Bank applications before 1997 & & & & $-4.76 * *(1.51)$ & $-2.86 *(1.36)$ & \\
\hline Bank applications 1997-1999 & & & & $-1.90 * *(0.57)$ & & \\
\hline Bank applications after 1999 & & & & & $1.90 * *(0.57)$ & \\
\hline Constant & $0.75(1.12)$ & $-0.57(1.52)$ & $-0.38(1.54)$ & $4.46(2.34)$ & $2.56(2.28)$ & \\
\hline Observations & 123 & 123 & 123 & 123 & 123 & \\
\hline \multicolumn{6}{|c|}{ Notes: $* * *=p<0.10 ; *=p<0.05 ; * *=p<0.01$} & \\
\hline
\end{tabular}

and 1999 were more likely to use consultants than founders who filed prior to 1997 but less likely to use consultants than founders who filed after 1999.

Performance impact of consultant use model (H4a and H4b)

Descriptive statistics and correlations for the variables used in the model predicting the performance of banks that used consultants are presented in Table III. Table IV shows the results of the model when ROE is the performance outcome measure. Model 1 represents the baseline model, comprised of only the control variables, while Model 2 includes the results of the full model. The full model suggests that banks whose founders use consultants at startup experience marginally better financial performance $(p<0.10)$ during the first three years of bank operations than the banks of founders who do not. This represents modest support for $H 4 a$ - banks that use a consultant at startup will see a positive impact on financial performance.

It is also worth noting that the inverse mills ratio (Mills Ratio), though only a control variable and not the primary variable of interest in the model, is statistically significant. This suggests that the inverse mills ratio is both detecting and correcting for selection bias in the model. Stated differently, the inverse mills ratio is correcting for the fact that unobserved factors related to consultant use are also related to consultant performance.

Table $\mathrm{V}$ shows the results of the effect of consultant use when a bank's Weiss rating, a multifactor composite measure of performance favored by bank regulators, is used. With this broader measure of performance, the model suggests that banks that use consultants at startup do not experience performance gains relative to banks that do not use consultants. Thus, $H 4 b$ is not supported.

\section{Additional analyses}

The equivocal results above on the performance effects of banks that use consultants led us to pursue additional analyses. Because the sample data includes the name of the consulting firm hired by the founder, it was possible to isolate individual consulting firm performance. In the overall sample, four of the consulting firms in the study were observed to account for more than 75 per cent of all consulting engagements, including banks that did not successfully start. The number of engagements performed by these firms ranged from 5 to 26 . 


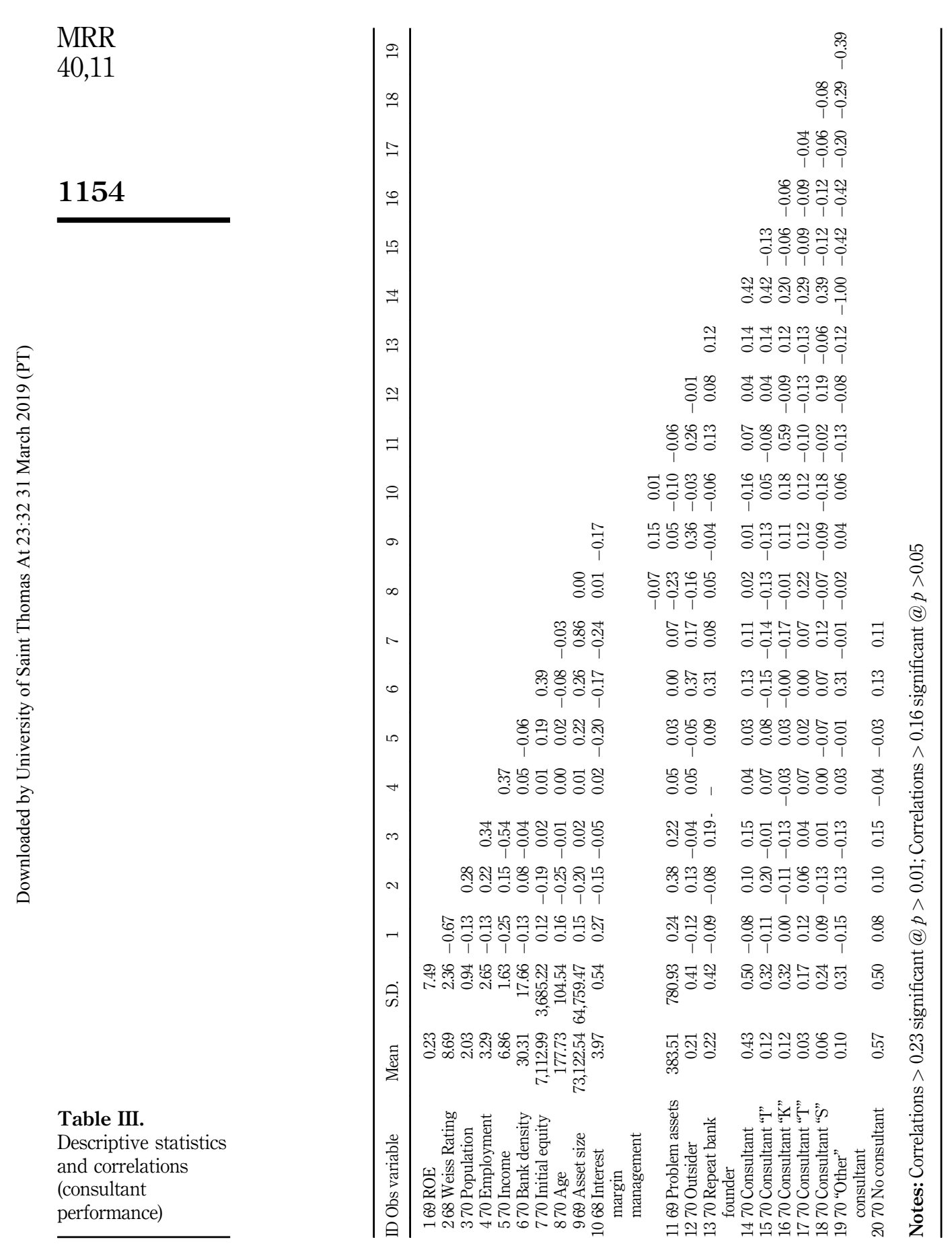




\begin{tabular}{|c|c|c|c|}
\hline Variable & Model 1 & Model 2 & \multirow{3}{*}{$\begin{array}{r}\text { performance of } \\
\text { new banks }\end{array}$} \\
\hline Population & $-0.57(1.19)$ & $-0.53(1.16)$ & \\
\hline Employment & $-0.10(0.34)$ & $-0.15(0.34)$ & \\
\hline Income & $-0.71(0.69)$ & $-0.64(0.68)$ & \multirow{5}{*}{1155} \\
\hline Bank density & $-0.08(0.05)$ & $-0.10 * * *(0.05)$ & \\
\hline Initial equity & $0.00(0.00)$ & $0.00(0.00)$ & \\
\hline Age & $0.01(0.01)$ & $0.01(0.01)$ & \\
\hline Asset size & $0.00 *(0.00)$ & $0.00(0.00)$ & \\
\hline Net interest margin management & $3.87 *(1.62)$ & $4.24 * *(1.59)$ & \multirow{10}{*}{$\begin{array}{r}\text { Table IV. } \\
\text { OLS Regression of } \\
\text { ROE performance } \\
(H 4 a)\end{array}$} \\
\hline Problem assets & $-0.003^{*}(0.001)$ & $-0.003^{*}(0.001)$ & \\
\hline Outsider & $-1.68(2.33)$ & $-1.69(2.27)$ & \\
\hline Repeat bank founder & $-1.16(2.27)$ & $-1.50(2.22)$ & \\
\hline Selection correction (Mills Ratio) & $3.72 *(1.84)$ & $5.74 * *(2.08)$ & \\
\hline Consultant & & $3.88 * * *(2.03)$ & \\
\hline Constant & $-12.84^{*}(9.24)$ & $-17.82 *(9.40)$ & \\
\hline$R^{2}$ & 0.35 & 0.39 & \\
\hline Observations & 68 & 68 & \\
\hline \multicolumn{2}{|c|}{ Notes: $* * *=p<0.10 ; *=p<0.05 ; * *=p<0.01$} & & \\
\hline Variable & Model 1 & Model 2 & \\
\hline Population & $0.42(0.30)$ & $0.44(0.30)$ & \\
\hline Employment & $0.13(0.09)$ & $0.12(0.09)$ & \\
\hline Income & $0.10(0.18)$ & $0.09(0.18)$ & \\
\hline Bank density & $-0.01(0.02)$ & $-0.01(0.02)$ & \\
\hline Initial equity & $0.00(0.00)$ & $0.00(0.00)$ & \\
\hline Age & $-0.004 * * *(0.002)$ & $-0.004 * * *(0.002)$ & \\
\hline Asset size & $0.00(0.00)$ & $0.00(0.00)$ & \\
\hline Net interest margin management & $-0.87 *(0.45)$ & $-0.87 *(0.45)$ & \\
\hline Problem assets & $0.001 * *(0.00)$ & $0.001 * *(0.00)$ & \\
\hline Outsider & $0.86(0.71)$ & $0.89(0.72)$ & \\
\hline Repeat bank founder & $-1.12 * * *(0.63)$ & $-1.13 * * *(0.63)$ & \\
\hline Selection correction (Mills Ratio) & $-0.62(0.53)$ & $-0.49(0.62)$ & Oable V. \\
\hline Consultant & & $0.23(0.58)$ & rence \\
\hline Observations & 67 & 67 & rating performance \\
\hline \multicolumn{3}{|c|}{ Notes: $* * *=p<0.10 ; *=p<0.05 ; * *=p<0.01$} & $(H 4 b)$ \\
\hline
\end{tabular}

Consulting firms that have completed four or fewer transactions are responsible of the remainder of the consulting engagements. Thus, to conduct these additional analyses, the original consultant data was segmented into a total of six subgroups: one for each of the four primary consulting firms that were identified, one for "other" (if a consulting firm other than one of the primary four firms was used) and one for "no consultant" (if no consultant was used). To preserve firm anonymity, the primary four consulting firms are referred to as consultant "I", consultant "K", consultant "T" and consultant "S".

After this segmentation, new analyses were conducted using the two measures of performance, ROE and Weiss rating. Table VI shows the results when ROE is the performance measure and Table VII shows the results when Weiss rating is the 





performance measure. Table VI (model 1) indicates that only founders who chose consultant " $T$ " performed better than banks who did not receive consulting help. Furthermore, Table VI Model 2 shows that banks that chose consultant " $T$ " also outperformed all other consulting choices (indicated by the negative and statistically significant coefficients for all other consulting choices). Table VII, which uses the Weiss rating as a measure of performance, shows a similar pattern of results. Consultant " $T$ " is preferable (albeit marginal at $p<0.10$ ) to the no consultant choice; the significant and negative coefficient on consultant " $T$ " indicates a lower Weiss rating (i.e. better performance) than no consultant. Similarly, in Table VII Model 2, when consultant " $T$ " is compared to all other consulting choices, they are all, with the exception of consultant " $K$ ", worse.

\section{Discussion and conclusion}

The primary goal of this paper was to identify and test conditions under which founders might engage outside consultants during the startup process. Drawing on a variety of literatures, hypotheses were developed to suggest that concerns over legitimacy, complexity and regulatory change could influence a bank founder's decision to invest its scarce startup resources in hiring a consultant. The complexity and regulatory change hypotheses were supported, but the legitimacy hypothesis was not; no relationship was observed between consultant use by prior banks and consultant use by subsequent banks. This relationship was further explored by conducting supplemental analyses (not reported here) and investigating other specification alternatives, including a nonlinear " $U$ " shaped specification for prior consultant use, as well as measuring prior consultant use using the gross number of prior banks that used consultants (rather than the proportion) and a relationship was still not observed. The lack of support for the legitimacy hypothesis suggests that new bank founders may assume that legitimacy can be conferred through means other than imitation.

On first pass, the failure to find a relationship seems odd, given the pervasiveness of consultant use among new banks (nearly 60 per cent of new banks used a consultant in the sample) and the "taken-for-granted" expectation by outsiders that new banks will indeed use them. (A South Florida Business Journal (2006) report linked a proposed new bank's unsuccessful launch attempt to the "unusual" strategy of not using a consultant.) However, a more careful examination of institutional theory (DiMaggio and Powell, 1983), specifically the imitation claims, highlights an important, but underemphasized aspect of the theory firms tend to imitate the activities of other similar firms often without a full understanding of the effectiveness of the practices. While some new banks may imitate the initial strategic choices of firms in their organizational set, other new banks may assume that the regulatory requirements of the industry automatically confer legitimacy and therefore deem imitation unnecessary to enhance legitimacy.

After developing hypotheses around the conditions under which founders would seek out consultants, the question of whether or not such consultants enhance firm performance was examined. Here, the findings are less clear: there was a modest positive relationship between new banks that used consultants and ROE performance, a traditional measure of bank profitability, but no relationship between consultant use and Weiss ratings, a multifactor, composite measure of performance preferred by regulators.

The differences in these results may have to do with the nature of each measure. ROE is a relatively elastic and responsive measure of performance that can vary widely from year to year. By contrast, Weiss ratings are relatively inelastic and "sticky" and are slow to change from year to year. Given that the sample comprised new banks, which by definition are fragile and unstable, their initial Weiss ratings are likely to reflect their general weak financial position and may remain unchanged until they reach a more mature state. This 
MRR 40,11

1158

makes it more difficult to observe a statistically significant effect in the models during the three year performance window of this study. For instance, one observation in the sample received the same Weiss rating in each of the three years covered in the study, despite the fact that its ROE improved markedly each year from -3.23, to 4.39 to 6.96.

Nonetheless, the fact that consultants may influence one measure of performance but not another should give founders pause when deciding whether to hire a consultant at startup. From a managerial perspective, founders should be clear about their objective in hiring a consultant. If they primarily seek to satisfy their financial stakeholders by maximizing the firm's financial performance, hiring a consultant at startup could be in the firm's best interest. On the other hand, if founders are more concerned with attending to the needs of regulators by effectively managing their firm's Weiss ratings, hiring a consultant may not pay off.

Finally, additional analyses were conducted where consultant performance was disaggregated to isolate the effects of specific consulting firms and determine whether the relationship between consultant use and performance was contingent on who was providing the consulting. There were two interesting results from this additional analysis. First, one consultant (" $T$ ") delivered higher profits and better Weiss ratings for their clients than all other consultants. Second, banks that used this same consultant (" $T$ ") also outperformed banks that did not use a consultant on both an ROE and Weiss ratings basis. In an effort to better understand this "high performing" consulting firm, it was discovered that one of the firm's principals was a former director of the state's bank regulatory division and had supervised more than 100 bank foundings during his tenure there. As such, consulting firm "T" may benefit from having access to specific experienced-based knowledge via this individual that enables it to outperform its peers.

Taken together, these findings imply that from an economic value creation standpoint, some consultants are "worth it", while others are not; choosing well matters and "caveat emptor" (buyer beware) applies. For example, consulting experience, measured by the number of prior consulting engagements (a logical criterion by which to choose a consultant), has no bearing on the bank's performance in this data set. The top two consulting firms in terms of the number of engagements both underperformed the "high performing" consulting firm that had fewer engagements. This suggests that a consulting firm's accumulated experience may not be a reliable indicator of its ability to improve performance. This logic is consistent with the argument that it may be more fruitful to focus on "fine-grained" measures of experience rather than experience in the aggregate (Argote et al., 2003).

Still, considering that a majority of new banks are spending an appreciable portion of their limited financial resources on consultants[5] and the economic payoff is uncertain, perhaps consultants also create value in other meaningful ways. One possibility is that hiring a consultant may signal important information to bank stakeholders such as regulators and investors. For example, DeVaughn and Leary (2010) noted that bank regulators sometimes "fast track" and expedite the bank approval process for new bank applications that meet certain criteria. Perhaps consultant-assisted new banks enjoy expedited approvals as well, as consultants are likely to have had repeated interactions with regulators and are thus more experienced and familiar with the subtleties, nuances and idiosyncrasies of successfully steering new banks through the approval process. If expediting the new bank approval process is a byproduct of using a consultant, then new bank investors, another important stakeholder, may also benefit - the sooner a new bank can open, the sooner it can began earning a return for its investors. 
From a policy making or regulatory perspective, the fact consultants seem to have only a modest effect on early new bank performance should be of some concern, especially if regulators believe that consultant-assisted new banks have been vetted in ways that unassisted new banks have not. While using a consultant may signal to regulators that a new bank has the "right stuff" for approval, it does not, unfortunately, signal better performance, which should be the ultimate goal given a bank regulator's mandate to closely monitor the health and stability of individual banks.

\section{Limitations and future research}

The results of this study provide several pathways for future research, both to address new questions, as well as the limitations of the study. One such limitation is this study's focus on a single state and industry. While the single location and industry design naturally controls for potential confounds associated with geography and industry, future research could test the hypotheses regarding consultant use in regulated and unregulated industries and in other locations to expand the understanding of the impact of legitimacy, complexity and change on consultant use and firm performance. A second limitation of this study concerns the use of archival data. While the data set is unique, it is difficult to definitively isolate the specific motivations and expectations of the founders with regard to their use of consultants. To address this issue, the theory building efforts in this paper were corroborated with actual accounts provided by bankers, consultants and regulators wherever possible. However, future research could contribute to the literature using a study design that relies on first person accounts, rather than archival data, to understand founder motivations for strategic decisions.

A final limitation concerns the generalizability of the results to other industries. While the US banking industry may be above average in terms of regulation, the findings are likely to hold in other industries that are characterized by high levels of regulation or regulatory change (e.g. health care, telecommunications, transportation, etc.). For example, the findings might be informative for healthcare firms who because of the passage of the Affordable Care Act in 2010 (and the possible repeal of this law), must navigate significant changes in the US health-care industry. Nevertheless, it remains to be seen whether the findings of this study might hold in more loosely regulated environments.

With regard to future research, additional studies might consider examining other motives, beyond those studied here, as to why founders might hire consultants, given that for most consultants there was an equivocal impact on firm performance. In this paper, the focus was on the financial value a new firm might derive from hiring a consultant. By focusing on the internal demands of a new firm, for example, future research may uncover additional ways that consultants create value and perhaps explain why founders seem eager to invest their limited startup resources in consultants. For instance, it could be the case that some founders view the decision to seek consulting help as an effective tool for allocating startup tasks that allows them the freedom to focus on higher value activities, such as raising startup capital, hiring managers and generating product demand. These are all possible motives for seeking consulting help at startup and may be worthy of investigation.

\section{Notes}

1. According to FDIC statistics and a report issued by the Federal Reserve Bank of Dallas researchers, between 2010 and 2015, only one new bank was launched in the USA. 
MRR

40,11

1160
2. While these regulatory changes technically affected all banks, from a practical standpoint, startup banks were most affected as the changes had a larger impact on decisions made at the start of operations (e.g. number of shareholders to seek, types of stock to issue, type of organizational structure to use, etc.). Such decisions would have been more difficult to implement in established banks.

3. For all indicator variables, yes $=1$ and no $=0$.

4. Problem assets are defined as bank loans that are more than 90 days past due plus loans that have been written off as uncollectible.

5. Consulting fees are estimated to be the second largest expense for startup banks after employee labor costs.

\section{References}

Anand, N., Garner, H.K. and Morris, T. (2007), "Knowledge-based innovation: emergence and embedding of new practice areas in management consulting firms", Academy of Management Journal, Vol. 50 No. 2, pp. 406-428.

Ancona, D.G. (1990), “Top management teams: preparing for the revolution,” in Carroll, J. (Ed.) Applied Social Psychology and Organizational Settings, Erlbaum, Hillsdale, NJ, pp. 99128.

Argote, L., McEvily, B. and Reagans, R. (2003), "Managing knowledge in organizations: an integrative framework and review of emerging themes", Management Science, Vol. 49 No. 4, pp. 571-582.

Austin, D.V., Anderson, D.F. and Bires, S.A. (1999), How to Charter a Commercial Bank, CCH, Riverwoods, IL.

Bandura, A. (1977), "Self-efficacy: toward a unifying theory of behavioral change", Psychological Review, Vol. 84 No. 2, pp. 191-215.

Bandura, A. (1984), "Recycling misconceptions of perceived self-efficacy", Cognitive Therapy and Research, Vol. 8 No. 3, pp. 231-255.

Burns, L.R. and Wholey, D.R. (1993), "Adoption and abandonment of matrix management programs: effects of organizational characteristics and interorganizational networks", Academy of Management Journal, Vol. 36 No. 1, pp. 108-138.

Chrisman, J.J., McMullan, E.W. and Hall, J. (2005), “The influence of guided preparation on the long-term performance of new ventures”, Journal of Business Venturing, Vol. 20 No. 6, pp. 769-791.

Chrisman, J.J., McMullan, W.E., Ring, J.K. and Holt, D.T. (2012), "A comparison of the impact of counseling assistance and entrepreneurship education on new venture performance", Journal of Entrepreneurship and Public Policy, Vol. 1 No. 1, pp. 63-83.

Davis, G. (1991), "Agents without principles?: The spread of the poison pill through the intercorporate network”, Administrative Science Quarterly, Vol. 36 No. 4, pp. 605-633.

Dess, G.G. and Beard, D.W. (1984), "Dimensions of organizational task environments", Administrative Science Quarterly, Vol. 29 No. 1, pp. 52-73.

Deephouse, D.L. (1996), “Does isomorphism legitimate?”, Academy of Management Journal, Vol. 39 No. 4, pp. 1024-1040.

DeVaughn, M.L. and Leary, M.M. (2010), "Antecedents of failure for newly chartered banks in the US banking industry”, Group \& Organization Management, Vol. 35 No. 5, pp. 666-695.

DiMaggio, P.J. and Powell, W.W. (1983), "The iron cage revisited: institutional isomorphism and collective rationality in organizational fields", American Sociological Review, Vol. 48 No. 2, pp. 147-160. 
Duncan, R.B. (1972), "Characteristics of organizational environments and perceived environmental uncertainty”, Administrative Science Quarterly, Vol. 17 No. 3, pp. 313-327.

Dyer, L.M. and Ross, C.A. (2008), "Seeking advice in a dynamic and complex business environment: impact on the success of small firms", Journal of Developmental Entrepreneurship, Vol. 13 No. 2, pp. 133-149.

Evan, W.M. (1966), "The organizational set: toward a theory of organizational relations", in Thompson, J.D. (Ed.), Approaches to Organizational Design, University of Pittsburgh Press, Pittsburgh, PA.

Fincham, R., Clark, T., Handley, K. and Sturdy, A. (2008), "Configuring expert knowledge: the consultant as sector specialist”, Journal of Organizational Behavior, Vol. 29 No. 8, pp. 1145-1160.

Finkelstein, S. and Hambrick, D.C. (1996), Strategic Leadership: Top Executives and Their Effects on Organizations, West Publishing Company, St. Paul, MN.

Haleblian, J. and Finkelstein, S. (1993), "Top management team size, CEO dominance, and firm performance: the moderating roles of environmental turbulence and discretion", Academy of Management Journal, Vol. 36 No. 4, pp. 844-863.

Haunschild, P.R. and Miner, A.S. (1997), "Modes of interorganizational imitation: the effects of outcome salience and uncertainty”, Administrative Science Quarterly, Vol. 42 No. 3, pp. 472-500.

Haveman, H.A., Russo, M.V. and Meyer, A.D. (2001), "Organizational environments in flux: the impact of regulatory punctuations on organizational domains, CEO succession, and performance", Organization Science, Vol. 12 No. 3, pp. 253-273.

Heckman, J. (1979), "Sample selection bias as a specification error", Econometrica, Vol. 47 No. 1, pp. 153-161.

Knoke, D. (1982), "The spread of municipal reform: temporal, spatial and social dynamics", American Journal of Sociology, Vol. 87 No. 6, pp. 1314-1339.

Kotter, J.F. (1982), The General Managers, Free Press, New York, NY.

Larsson, E., Hedelin, L. and Gärling, T. (2003), "Influence of expert advice on expansion goals of small businesses in rural sweden", Journal of Small Business Management, Vol. 41 No. 2, pp. 205-212.

March, J.G. and Olsen, J.P. (1976), Ambiguity and Choice in Organizations, Universitesforlaget, Bergen.

Meyer, J. and Rowan, B. (1977), "Institutionalized organizations: Formal structures as myth and ceremony", American Journal of Sociology, Vol. 83 No. 2, pp. 340-363.

Miller, D. (1992), “Environmental fit versus internal fit”, Organization Science, Vol. 3 No. 2, pp. 159-178.

Milliken, F.J. (1990), "Perceiving and interpreting environmental change: an examination of college administrators' interpretation of changing demographics", Academy of Management Journal, Vol. 33 No. 1, pp. 42-63.

Milliken, F.J. (1987), "Three types of perceived uncertainty about the environment: state, effect, and response uncertainty”, Academy of Management Review, Vol. 12 No. 1, pp. 133-143.

Palmer, T. (2016), "Management consulting in the US: Market Research Report", Management Consulting Market Research Report NAICS 54161, available at: http://clients1.ibisworld.com/ reports/us/industry/default.aspx?entid=1421 (accessed 12 January 2017).

Pfeffer, J. and Salancik, G.R. (1978), The External Control of Organizations, Harper and Row, New York, NY.

Schaffer, R.H. and Thompson, H. (1992), "Successful change programs begin with results", Harvard Business Review, pp. 80-89.

Semadeni, M. (2006), "Minding your distance: how management consulting firms use service marks to position competitively", Strategic Management Journal, Vol. 27 No. 2, pp. 169-187.

Smith, J. (2013), “Wanted: health-care legal experts”, The Wall Street Journal, 17 June, pp. B1+. 
MRR

40,11

1162
Soriano, D.R. (2003), "The impact of consulting service on SPANISH firms", Journal of Small Business Management, Vol. 41 No. 4, pp. 409-416.

South Florida Business Journal (2006), Florida Coast Bank Applies for Charter, 17 January.

Stevenson, H.H. and Sahlman, W.A. (1988), "How small companies should handle advisors", Harvard Business Review, Vol. 66 No. 2, pp. 128-134.

Thompson, J.D. (1967), Organizations in Action, McGraw-Hill, New York, NY.

Tung, R. (1979), "Dimensions of organizational environments: an exploratory study of their impact on organizational structure", Academy of Management Journal, Vol. 22 No. 4, pp. 672-693.

Werr, A. and Pemer, F. (2005), "Purchasing management consultants - from personal ties to organizational procedures", In Academy of Management Proceedings (Meeting Abstract Supplement), Vol. 2005 No. 1, pp. B1-B6.

\section{Corresponding author}

Myleen Leary can be contacted at: myleen.leary@montana.edu

For instructions on how to order reprints of this article, please visit our website: www.emeraldgrouppublishing.com/licensing/reprints.htm

Or contact us for further details: permissions@emeraldinsight.com 